\title{
ОФТАЛЬМОХІРУРГІЯ
}

Денисюк О. Ю.

Національна медична академія післядипломної освіти імені П. Л. Шупика

\section{СПОСІБ ОЦІНЮВАННЯ ВПЛИВУ ХІРУРГІЧНОГО ЛІКУВАННЯ КАТАРАКТИ НА ПРОГРЕСУВАННЯ ВІКОВОЇ МАКУЛЯРНОЇ ДЕГЕНЕРАЦІЇ}

\begin{abstract}
У роботі наводяться результати дослідження впливу хірургічного лікування вікової катаракти на прогресування вікової макулярної дегенерації (ВМД).

Мета роботи - розробити спосіб оцінки впливу хірургічного лікування катаракти на прогресування вікової макулярної дегенерації.

У 82 хворих (93 ока) вивчено вплив параметрів факоемульсифікації (ФЕК), операційні та післяопераційні ускладнення на прогресування ВМД. Встановлено, що факторами ризику прогресування ВМД після хірургічного лікування $є$ щільність ядра кришталика по Buratto, тривалість операції, обсяг іригаційної рідини, показник кумулятивної розсіяної енергії (середня потужність і експозиція лінійного ультразвуку та середня торсійна амплітуда і торсійний час), післяопераційне запалення. Розроблено шкалу бальної оцінки прогресування вікової макулярної дегенерації після хірургічного лікування катаракти.

Ключові слова: вікова катаракта, хірургічне лікування, ускладнення, вікова макулярна дегенерачія, прогресування.
\end{abstract}

Катаракта - це дегенеративне захворювання кришталика ока, яке найчастіше зустрічається у осіб, старших за 60 років [9]. Саме катаракта часто є причиною значного зниження зору у людей похилого віку. Серед причин зворотної сліпоти по всьому світу катаракта займає лідируючі позиції. На сьогоднішній день ультразвукова факоемульсифікація (ФЕК) є золотим стандартом відновлення зору та вважається основним методом іiі лікування. Головним параметром ФЕК $є$ показник кумулятивної розсіяної енергії (середня потужність та експозиція лінійного ультразвуку i середня торсійна амплітуда і торсійний час), який характеризується певними режимами [10].

Відомо, що у пацієнтів старших за 60 років, які перебувають у групі ризику по розвитку вікової катаракти, нерідко зустрічається вікова макулярна дегенерація (ВМД) - прогресуюче ураження центральної зони сітківки. У зв'язку із зростанням у популяції частки осіб похилого віку очікується, що соціальні та економічні наслідки сліпоти від вищевказаних захворювань у найближчі десятиліття будуть істотно зростати [1].
Частота ВМД зростає паралельно зі збільшенням віку хворих. Так, у віковій групі від 52 до 64 років вона становить $1,6 \%$, від 65 до 74 років - 15\%, від 75 до 84 років $-25 \%$, а серед осіб старших за 85 років $-30 \%$. За даними ВОО3, частка населення старшої вікової групи в економічно розвинених країнах становить близько $20 \%$, а до 2050 р. зросте, ймовірно, до $33 \%$ [7]. Відповідно, у зв'язку з очікуваним збільшенням тривалості життя, неухильним зростанням атеросклерозу і супутньої патології проблема ВМД залишається найбільш актуальною. До того ж в останні роки намітилася чітка тенденція до «омолодження» даного захворювання [5].

Соціально-медична значимість патології обумовлена швидкою втратою центрального зору і втратою загальної працездатності. Ступінь тяжкості процесу і втрати центрального зору залежить від форми ВМД і близькості процесу до центральної ямки сітківки. Помічено, що парне око уражається не пізніше, ніж через 5 років після захворювання першого [6].

Незважаючи на сучасні досягнення хірургії катаракти, що забезпечує зменшення іiї травматичної дії, 
триває активна дискусія про можливий негативний вплив екстракції катаракти на стан макулярної зони сітківки, зокрема, на виникнення і прогресування ВМД [3]. Слід зауважити, що хірургічне видалення катаракти може сприяти прогресуванню захворювання у пацієнтів, які вже мають початкові зміни в макулярній зоні сітківки $[2,4,8]$. За даними світової літератури, немає єдиної точки зору щодо негативного впливу ФЕК на прогресування ВМД.

Нами повідомлялося раніше про вплив факоемульсифікації на прогресування вікової макулярної дегенерації в ранньому та віддаленому періодах [7].

Мета дослідження - розробити спосіб оцінювання впливу хірургічного лікування катаракти на прогресування вікової макулярної дегенерації.

Матеріали та методи. Під нашим наглядом знаходилось 86 хворих (93 ока) - 37 чоловіків та 49 жінок у віці 60-82 роки з катарактою та ВМД.

Усім пацієнтам у динаміці виконували візометрію, рефрактометрію, тонометрію за допомогою пневмотонометра, статичну периметрію, дослідження кольоросприйняття, офтальмоскопію (пряму, бінокулярну, за допомогою безконтактних лінз +78 та +90 дптр та лінзи Гольдмана), при необхідності - флуоресцентну ангіографію. При недостатньо прозорих оптичних середовищах виконували А та В сканування. Оптичну когерентну томографію виконували на апараті Cirrus HD 5000 Carl Zeiss; використовували програму macular cube 512-128-30 .

Ступінь ВМД оцінювали за класифікацією AREDS.

Усім була виконана ФЕК з імплантацією м'якої інтраокулярної лінзи на апараті Infiniti фірми Alcon. Параметри визначались щільністю ядра.

Вивчали характер, частоту та тривалість операційних, ранніх та пізніх післяопераційних ускладнень та їхній вплив на прогресування ВМД після хірургічного лікування катаракти. Також вивчали інші ймовірні фактори ризику прогресування ВМД.

Термін спостереження склав 1,5 року.

Результати та їх обговорення. Обстеження пацієнтів через 6 місяців, 1 рік, 1,5 року після ФЕК показало, що гострота зору підвищилась на 77 очах (82,8\%), збереглась на доопераційному рівні на 5 очах (5,37\%) і знизилась на 11 очах (11,83\%). При обстеженні встановлено прогресування ВМД на 19 очах (20,43\%) та на 12 очах (12,90\%) ВМД виявили вперше.

Під час дослідження мали місце типові інтраопераційні та післяопераційні ускладнення: розрив задньої капсули кришталика, гіфема, набряк рогівки, післяопераційні запалення. Їхня частота склала 7,52\%.

У ході клінічних спостережень нами було встановлено, що одним із факторів ризику прогресування ВМД виявлялося післяопераційне запалення.

Під час дослідження ми фіксували тривалість операції, об’єм використаної іригаційної рідини, вимірювали показники ультразвукової дії - кумулятивної розсіяної енергії (середня потужність і експозиція лінійного УЗД та середня торсійна амплітуда і торсійний час) - та вивчали їхній вплив на подальше прогресування ВМД.

Для оцінки впливу хірургічного лікування катаракти на прогресування ВМД ми вивчали безпосередній вплив ультразвуку на прогресування ВМД, а також вимірювали вплив показників факоемульсифікації катаракти у відповідності зі шкалою бальної оцінки, розробленою нами - від 0 до 5 балів, у якій 0 балів відповідає мінімальному впливу ультразвуку, а 5 - максимальному. Шкалу бальної оцінки факторів ризику прогресування ВМД після хірургічного лікування катаракти ми розробили у вигляді кількісної оцінки балів таких груп показників:

1. Щільність ядра кришталика по Buratto:

- відсутність катаракти, факосклероз - 0;

- перший ступінь щільності ядра - 1;

- другий ступінь щільності ядра - 2;

- третій ступінь щільності ядра - 3;

- четвертий ступінь щільності ядра - 4;

- п'ятий ступінь щільності ядра - 5 .

2. Тривалість операції по видаленню катаракти.

- 5-8 хв. -0 ;

- 8-11 хв. -1 ;

- 11-14 хв. -2 ;

- 14-17 хв. -3 ;

- 17-20 хв. - 4;

- більше 20 хв. - 5 .

3. Об 'єм іригаційної рідини:

- 75-125 мл-0;

- 126-175 мл - 1;

- 176-225 мл-2;

- 226-275 мл-3;

- 275-325 мл-4;

- більше 326 мл - 5 .

4. Показник кумулятивної розсіяної енергї (середня потужсність та експозиція лінійного ультразвуку і середня торсійна амплітуда та торсійний час).

- 0-6-1;

- 6,01-12,0-2;

- 12,01-18,0-3;

- 18,01-24,0 - 4;

- 24,01 і більше -5 .

5. Післяоперачійне запалення:

- запальних явищ нема - 1 ;

- опалесценція вологи передньої камери (ефект Тиндаля) -2 ;

- згладженість рельєфу райдужной оболонки i млява фотореакція - 3;

- згладженість рельєфу райдужной оболонки i млява фотореакція, циліарна хворобливість - 4;

- ексудат у передній камері - 5 .

На підставі суми одержаних балів перерахованих вище показників прогнозували стан сітківки і при 2-5 
балах свідчили про низький рівень ризику прогресування вікової макулярної дегенерації, при 6-10 балах - про помірний ризик, при 11-15 балах - про середній ризик, при 16-20 балах про високий ризик, а при 2125 балах - про дуже високий ризик (заявка на винахід а 201803738 від 06.04.2018; заявка на корисну модель u 201803735 від 06.04.2018).

У нашому дослідженні було встановлено, що візуальний ефект хірургічного лікування катаракти в найближчі та віддалені строки спостереження у хворих з ВМД здебільшого визначається їі прогресуванням. Також від цього залежить і задоволеність пацієнтом проведеним лікуванням.

На нашу думку, встановлені іншими дослідниками, а також нами фактори ризику прогресування ВМД після хірургічного лікування катаракти хоча $\mathrm{i}$ визначають прогресування ВМД, але не являються вирішальними. Вивчення нових механізмів прогресування ВМД після хірургічного лікування катаракти представляються нам вельми перспективними.

\section{Висновки}

1. Хірургічне лікування катаракти є фактором ризику прогресування вікової макулярної дегенерації.

2. Розроблена нами бальна шкала оцінки прогресування вікової макулярної дегенерації після хірургічного лікування вікової катаракти дозволяє об'єктивно оцінити ризик прогресування вікової макулярної дегенерації після факоемульсифікації вікової катаракти.

\section{Література}

1. Будзинская М. В. Современные подходы к лечению и профилактике возрастной макулярной дегенерации / М. В. Будзинская, М. В. Воробьева, Т. Н. Киселева [и др.] // Клиническая офтальмология. - 2007. - Т. 8, № 2. - С. 78-82.

2. Журавлева Л. В. Динамика показателей про- и антиоксидантного статуса у больных возрастной макулодистрофией при использовании препарата Рексод / Л. В. Журавлева, Э. В. Бойко, И. В. Чурилова [и др.] // VI Всероссийская. школа офтальмолога: Сб. науч. тр. - М., 2007. - С. 275-283.
3. Капшук Н. I. Оптимізація факоемульсифікації у хворих на вікову макулярну дегенерацію: автореф. дис... кандидата мед. наук: спец. 14.01.18 «Офтальмологія» / Н. І. Капшук. - Одеса, 2013. $-18 \mathrm{c}$.

4. Капшук Н. И. Фактор риска прогрессирования возрастной макулопатии и макулодистрофии после ультразвуковой факоэмульсификации / Н. И. Капшук, С. К. Дмитриев // Сучасні медичні технології. - 2012. - № 2. - С. 121-122.

5. Еднева Я. Н. Гемодинамика глаза у больных «сухой» формой склеротической макулодистрофии до и после комбинированной аргонлазерной стимуляции / Я. Н. Еднева, Э. М. Миронова, О. С. Абрамова // Лазерные методы лечения и ангиографические исследования в офтальмологии: Сб. науч. тр. - М., 1983. - С. 85-88.

6. Ермакова Н. А. Современные методы диагностики и лечения возрастной макулярной дистрофии / Н. А. Ермакова, О. Ц. Рабданова // VI Всероссийская школа офтальмологов: Сб. науч. тр. - М., 2007. - С. 416-422

7. Рыков C. A. Влияние факоэмульсификации на прогрессирование возрастной макулярной дегенерации в раннем и отдаленном периодах / С. А. Рыков, С. Ю. Могилевский, О. Ю. Денисюк // Питання експериментальної та клінічної медицини: Збірник статей. - 2014. - Вип. 18, Т. 4. C. $120-126$.

8. Armbrecht A. M. Cataract surgery in patients with age-related macular degeneration: one year outcomes. / A. M. Armbrecht, C. Findlay, P. A. Aspinall [et al.] // J. Cataract. Refract. Surg. - 2003. Vol. 29. - P. 686-693.

9. ArnarssonA. Risk factors fornuclearlensopacification: the Reykjavik Eye Study. / A. Arnarsson, F. Jonasson, H. Sasaki [et al.] // Dev Ophthalmol. - 2002. - Vol. 35. - P. 12-20.

10. Foran $S$. Causes of visual impairment in two older population cross-sections: the Blue Mountains Eye Study / S. Foran, J. J. Wang, P. Mitchell // Ophthalmic Epidemiol. - 2003. - Vol. 10. - P. 215-225.

\section{СПОСОБ ОЦЕНИВАНИЯ ВЛИЯНИЯ ХИРУРГИЧЕСКОГО ЛЕЧЕНИЯ КАТАРАКТЫ НА ПРОГРЕССИРОВАНИЕ ВОЗРАСТНОЙ МАКУЛЯРНОЙ ДЕГЕНЕРАЦИИ}

\section{О. Ю. Денисюк}

В работе приводятся результаты исследования влияния хирургического лечения возрастной катаракты на прогрессирование возрастной макулярной дегенерации (ВМД). Цель работы - разработать способ оценки влияния хирургического лечения катаракты на прогрессирование возрастной макулярной дегенерации.

У 82 больных (93 глаза) изучено влияние параметров факоэмульсификации (ФЭК), а также операционные и послеоперационные осложнения на прогрессирование ВМД. Установлено, что факторами риска прогрессирования ВМД после хирургического лечения являются плотность ядра хрусталика по Buratto, продолжительность операции, объем ирригационной жидкости, показатель кумулятивной рассеянной энергии (средняя мощность и экспозиция линейного ультразвука, а также средняя торсионная амплитуда и торсионное время), 
послеоперационная воспалительная реакция. Разработана шкала балльной оценки прогрессирования возрастной макулярной дегенерации после хирургического лечения катаракты.

Ключевые слова: возрастная катаракта, хирургическое лечение, осложнения, возрастная макулярная дегенерачия, прогрессирование.

\section{METHOD FOR EVALUATION OF THE INFLUENCE OF SURGICAL TREATMENT OF THE CATARACT ON THE PROGRESS OF AGE MAGENTARY DEGENERATION}

O. Yu. Denysyuk

National Medical Academy of Postgraduate Education named after P. L. Shupyk Kyiv, Ukraine

The paper presents the result of the study of the effect of surgical treatment of age-related cataract on the progression of age-related macular degeneration (AMD). The aim of the work is to develop a method for evaluating the effect of surgical cataract treatment on the progression of age-related macular degeneration.

In 82 patients (93 eyes), the influence of the parameters of phacoemulsification (PHACO), as well as operational and postoperative complications on the progression of $\mathrm{AMD}$, was studied. It has been established that the risk factors for the progression of AMD after surgical treatment are Buratto lens core density, operation time, irrigation fluid volume, cumulative scattered energy (mean power and linear ultrasound exposure and mean torsion amplitude and torsion time) and postoperative inflammatory response. A scale was developed for assessing the progression of age-related malular degeneration after surgical treatment of cataracts.

Key words: age-related cataract, surgical treatment, complications, age-related macular degeneration, progression.

Стаття надійшла до редакції 09.08.2018 p.

К. О. Усенко

Національна медична академія післядипломної освіти імені П. Л. Шупика - м. Київ, Україна

\section{МОДИФІКОВАНИЙ МЕТОД ХІРУРГІЧНОГО ЛІКУВАННЯ ПТЕРИГІУМА}

У роботі приведено дані про ефективність розробленого нами модифікованого хірургічного методу лікування птеригіума, який полягає у такому: проводиться повне його видалення, яке відрізняється від класичної методики тим, що видалення птеригіума проводиться разом 3 його ростовою зоною. Після цього виконується 30 -ти секундна аплікація $0,02 \%$-им розчином мітоміцину $\mathrm{C}$, а далі проводиться дослідження у видаленому операційному матеріалі наявності мутацій гена V600Е кінази BRAF. Встановлено, що розроблена методика дозволила знизити частоту ранніх і пізніх післяопераційних ускладнень, а також післяопераційних рецидивів. Термін спостереження склав 1 рік. У результаті цього дослідження виявлена наявність гена V600Е кінази BRAF є достовірним прогнозуванням майбутнього рецидиву птеригіума. Також у роботі вперше проводилися дослідження BRAF мутації при птеригіумі та аналіз зв'язку їі наявності та післяопераційних рецидивів.

Ключові слова: птеригіум, хірургічне лікування, модифікований метод рецидивування, BRAF мyтайія. 